\title{
PERAN PEMBELAJARAN MENGGUNAKAN TUTOR TEMAN SEBAYA DALAM MENINGKATKAN PERILAKU REMAJA TENTANG PENDEWASAAN USIA PERKAWINAN
}

\author{
Ni Luh Putu Sri Erawati, Gusti Ayu Mandriwati, Juliana Mauliku \\ Dosen Jurusan Kebidanan Poltekkes Denpasar \\ erawatiputu@gmail.com
}

\begin{abstract}
The early marriage problem can be anticipated by giving the teenagers an education about maturation age of marriage. This research aims to notice the role of peer group teaching approach to increase teenagers behavior about maturation age of marriage system in teenagers organization of Abiansemal District, Badung Regency. This designed with Experiment Pretest and Posttest Control Group Design. The variables are knowledge, attitude, and practice about maturation age in marriage, with the interval scale. The data was collected by test, which are written test. There were 17 cases had been found. Sixs cases were intervention group and 11 cases were control group. This research fount significan different between behavior about maturation age of marriage system in teenagers organization of Abiansemal District, Badung Regency.Teenagers behavior about maturation age of marriage system in case intervention group before and after learning $(p=0,046)$. in case control group ( $p=0,005)$. Conclution the role of peer group in teaching approach to increase teenagers behavior about maturation age of marriage system in teenagers organization of Abiansemal District, Badung
\end{abstract}

Keywords : Peer group, Teenagers, behavior, Maturation age of marriage

Abstrak : Masalah pernikahan usia dini bisa diantisipasi dengan memberikan pendidikan tentang Pendewasaan Usia Perkawinan (PUP) kepada para remaja. Penelitian ini bertujuan mengetahui peran pembelajaran menggunakan pendekatan tutor teman sebaya dalam meningkatan perilaku remaja tentang PUP pada remaja Sekehe Teruna Teruni di Kecamatan Abiansemal, Badung. Rancangan yang digunakan adalah Eksperimen Pretest dan Postest Control Group Design. Variabel penelitian: pengetahuan, sikap, dan praktik tentang PUP dengan skala interval. Data dikumpulkan dengan kuesioner. Sampel yang ditemukan sebanyak 17 kasus. Enam kasus sampel intervensi, dan 11 kasus sampel kontrol. Hasil penelitian menunjukkan ada perbedaan yang signifikan rata-rata nilai perilaku PUP sampel intervesi sebelum dan sesudah diberi pembelajaran $(p=0,046)$. Nilai perilaku PUP sampel kontrol sebelum dan sesudah diberi pembelajaran $(p=0,005)$. Simpulan penelitian ini, bahwa pembelajaran menggunakan tutor teman sebaya berperan meningkatkan perilaku pendewasaan usia perkawinan pada STT di Kecamatan Abiansemal.

Kata Kunci: Tutor Teman Sebaya, Perilaku Remaja, Pendewasaan Usia Perkawinan 


\section{Pendahuluan}

Pendewasaan Usia Perkawinan (PUP), bertujuan mewujudkan keluarga sejahtera degan menurunkan terjadinya kesakitan, kecacatan, dan kematian akibat gangguan kesehatan organ reproduksi pada wanita. Program PUP diluncurkan oleh Badan Koordinasi Keluarga Berencana Nasional, dan merekomendasikan usia pernikahan paling muda umur 21 tahun bagi wanita dan 25 tahun bagi pria ${ }^{1}$. Pada kenyataanya program PUP belum sejalan dengan undang-undang perkawinan yang berlaku di Indonesia, yang merekomendasikan usia pernikahan paling dini 16 tahun bagi wanita, dan 19 tahun bagi pria ${ }^{2}$. Hal ini memberi peluang bagi remaja untuk melangsungkan perkawinan pada usia dini. Perkawinan usia dini biasanya dipicu oleh karena kehamilan di luar nikah, sebagai akibat dari pergaulan seksual bebas.

Hasil Riset Kesehatan Dasar tahun 2010, menemukan wanita Indonesia yang menikah usia 10 sampai 14 tahun sebanyak 0,2 \%, sedangkan yang menikah usia 15 sampai 19 tahun $11,7 \% .^{3}$ Hasil pengamatan peneliti pada satu banjar di Desa Sukawati Kabupaten Gianyar (2013), dimana terdapat 10 pasang pengantin baru, sembilan pasang di antaranya semua pengantin wanita berusia di bawah 20 tahun, dan sudah hamil sebelum menikah. Wanita usia di bawah 20 tahun masih tergolong kelompok remaja, per-kembangan organ reproduksinya belum cukup matang, sehingga belum siap menerima kehamilan. Penyulit yang sering terjadi pada ibu hamil yang usianya kurang dari 20 tahun, antara lain, keguguran, bayi lahir belum cukup bulan, perdarahan setelah persalinan, anemia, pre eklampsi, dan eklamsi. Usia perkawinan yang sehat untuk wanita adalah umur 20 tahun sampai umur 34 tahun $^{4}$.

Masa remaja berada pada kehidupan yang sangat menentukan bagi kehidupan selanjutnya, apabila remaja tidak berperilaku sehat maka salah satu dari lima transisi kehidupan remaja yakni memulai kehidupan berkeluarga, tidak akan berhasil mencapai keluarga sejahtera. Pada umumnya remaja mempunyai permasalahan yang terkait dengan pemahaman tentang perkembangan organ reproduksi, teman intim, pola asuh orang tua di rumah, rencana pernikahan, dan masalah pendidikan. Jika remaja membahas permasalahan ini, mereka lebih cendrung berbagi pengalaman dengan teman sebayanya dibandingkan dengan orang tuanya, guru di sekolah, maupun orang- 
orang yang dianggap menguasai permasalahan. Mereka sangat percaya dan merasa aman mencurahkan semua permasalahan yang dialami dengan teman sebayanya. Dengan demikian remaja perlu mempunyai komunitas yang sehat untuk berkomunikasi secara bebas antar sesama remaja. Komunitas yang dimaksud adalah organisasi sosial remaja yang didukung oleh masyarakat setempat ${ }^{1}$.

Kelompok Sekehe Teruna Teruni (STT), merupakan satu organisasi sosial masyarakat di Bali, yang bisa berperan sebagai komunitas kehidupan remaja. Anggotanya terdiri dari para remaja putra dan putri yang termasuk menjadi satu kelompok banjar/desa di Bali. Organisasi STT merupakan wahana yang strategis dijadikan media komunikasi dalam memecahkan masalah antar remaja, namun selama ini kegiatan yang dilakukan masih sekitar kegiatan yang bersifat spiritual masyarakat di Bali. Organisasi ini perlu diberdayakan dalam penerapan program PUP dengan memberi pembelajaran tentang PUP kepada para anggotanya. Salah satu metode yang bisa digunakan adalah pendekatan menggunakan teman sebaya sebagai fasilitator pembelajaran, sehingga mereka bisa secara bebas saling mencurahkan isi hati antara temannya.
Metode ini disebut metode pendekatan tutorial teman sebaya.

Selama ini BKKBN Provinsi Bali dengan jajarannya di masing-masing kabupaten kota di Provinsi Bali telah menggunakan organisasi STT sebagai media sosialisasi materi Triad Kesehatan Reproduksi remaja yang mencakup: Seksualitas, HIV/Aids, dan Narkoba. Metoda yang digunakan masih terbatas pada metode ceramah dengan media pembelajaran berbentuk leaflet. Belum pernah menggunakan metode pembelajaran kooperatif, khususnya pembelajaran dengan menggunakan pende-katan tutorial teman sebaya.

Pembelajaran menggunakan pendekatan tutorial teman sebaya adalah metode pembelajaran dengan proses belajar berulang-ulang, berlangsung terus menerus, antara pasangan sasaran belajar. Sasaran belajar dihadapkan pada masalah yang sama, dan mendapat mengalaman belajar berulang-ulang, berbagi informasi secara bergantian dengan pasangannya. Dengan demikian sasaran belajar lebih mudah untuk mengenal dan mengingat materi pelajaran yang dipelajari, karena ada ketergantungan positif dengan temannya yang sedang berperan sebagai tutor ${ }^{5}$. 
Penelitian di Sudimoro $^{6}$ tentang Secara umum penelitian ini bertujuan untuk pendekatan kooperatif tutor sebaya mengetahui peran pembelajaran menggunamenemukan bahwa metode pembelajaran kan tutor teman sebaya dalam tutor teman sebaya, efektif untuk meningkatkan peilaku PUP pada remaja meningkatkan motivasi, kedisiplinan dan prestasi belajar Siswa Kelas VII A SMP Negeri 3 Sudimoro. Penelitian ini juga didukung dengan penelitian lainnya tentang penerapan metode pembelajaran tutorial teman sebaya hasilnya menunjukkan bahwa ada pengaruh positif metode tutor teman sebaya terhadap peningkatan hasil belajar berdasarkan regulasi dengan kontribusi $17,4 \% .^{7}$ Penelitian lainnya ${ }^{8}$ juga menyatakan bahwa ketuntasan prestasi belajar siswa dengan penerapan metode pembelajaran tutor sebaya pada siklus pembelajaran ke III mencapai ketuntasan belajar 86,7 \%, dari target ketuntasan belajar $85 \%$. Dari ketiga penelitian tersebut di atas, semuanya menemukan bahwa metode pembelajaran menggunakan tutor teman sebaya efektif meningkatkan hasil belajar sasaran belajar. Berdasarkan uraian di atas, masalah penelitian ini adalah “Apakah pembelajaran menggunakan tutor teman sebaya berperan dalam meningkatkan perilaku PUP pada remaja Sekehe Teruna Teruni di Kecamatan Abiansemal Kabupaten Badung tahun 2015”.

Abiansemal Kabupaten Badung tahun 2015. Secara khusus penelitian ini bertujuan untuk menganalisis perbedaan rata-rata nilai perilaku PUP sampel kelompok intervensi sebelum dan sesudah diberi pembelajaran PUP, menganalisis perbedaan rata-rata nilai perilaku PUP kelompok sampel kontrol sebelum dan sesudah diberi pembelajaran PUP dan menganalisis perbedaan rata-rata nilai perilaku PUP antara sampel kelompok intervensi dan sampel kelompok kontrol setelah diberi pembelajaran PUP.

\section{Metode}

Jenis penelitian ini adalah quasi eksperimen dengan rancangan Pretest Postest Control Group Design 9 . Penelitian ini dilaksanakan di Kecamatan Abiansemal Kabupaten Badung, dari Bulan Januari sampai dengan Oktober 2015. Populasi dan Sampel penelitian ini adalah Remaja pengelola STT di Kecamatan Abiansemal, Kabupaten Badung Tahun 2015 yang berasal dari 18 banjar yang ada di Kecamatan Abiansemal dengan latar belakang pendidikan SMA/SMK dan 
Perguruan Tinggi. Teknik Sampling diperoleh hasil pretest $(p=0.177)$ dan penelitian ini, menggunakan Purposive posttest $(p=0.395)$ yang artinya data tidak Claster Sampling. Besar sampel yang berdistribusi normal sehingga data dianalisis diperoleh sebanyak 17 orang. Variabel menggunakan Uji Wilcoxon dengan nilai $\mathrm{p}<$ Bebas Penelitian ini adalah Pembelajaran 0,05.

PUP menggunakan pendekatan tutor teman sebaya. Variabel terikatnya adalah Perilaku PUP (pengetahuan, sikap, dan Praktik PUP). Pengumpulan data dilaksanakan dengan menggunakan kuesioner untuk mengumpulkan data pengetahuan, sikap dan praktik Pendewasaan Usia Perkawinan. Kuesioner yang digunakan sudah dilakukan uji validitas isi, penampilan dan reliabilitasnya.

\section{Hasil Penelitian}

Karakteristik subjek penelitian disajikan berdasarkan kelompok intervensi sejumlah 6 orang dan kelompok kontrol sejumlah 11 orang sehingga total sampel sebesar 17 orang. Karakteristik subjek penelitian diperoleh melalui analisis univariabel yang disajikan pada Tabel 1.

Data yang dikumpulkan dalam bentuk numerik. Dari hasil uji normalitas data dengan menggunakan ShapiroWilk

Tabel 1

Karakteristik Sampel Kelompok Intervensi dan kelompok kontrol Berdasarkan Umur, Pendidikan dan Jenis Kelamin

\begin{tabular}{lcccccc}
\hline \multicolumn{1}{c}{$\begin{array}{c}\text { Karakteristik Subjek } \\
\text { Penelitian }\end{array}$} & \multicolumn{2}{c}{ Kelompok Intevensi } & \multicolumn{2}{c}{ Kelompok Kontrol } & \multicolumn{2}{c}{ Total } \\
\cline { 2 - 7 } & $\mathrm{n}$ & $(\%)$ & $\mathrm{n}$ & $(\%)$ & $\mathrm{n}$ & $(\%)$ \\
\hline Umur & 0 & 0 & 5 & 45,45 & 5 & 29,41 \\
$\quad<21$ Tahun & 6 & 100 & 6 & 54,55 & 12 & 70,59 \\
$\quad$ 21 -24 tahun & & & & & & \\
Pendidikan & 2 & 33,33 & 9 & 81,82 & 11 & 64,71 \\
$\quad$ Menengah & 4 & 66,67 & 2 & 18,18 & 6 & 35,29 \\
$\quad$ Tinggi & & & & & & \\
Jenis Kelamin & 1 & 16,67 & 0 & 0 & 1 & 5,88 \\
$\quad$ Perempuan & 5 & 83,33 & 11 & 100 & 16 & 94,12 \\
$\quad$ Laki-laki & & & & & & \\
\hline
\end{tabular}

Tabel 1 menunjukkan bahwa dari seluruh subjek penelitian sebagian besar (70,59\%) berusia 21 - 24 tahun, sebagian besar
$(64,71 \%)$ berpendidikan menengah dan mayoritas berjeni kelamin laki - laki $(94,12 \%)$. 
Tabel 2

Perbedaan Rata - rata Nilai Perilaku Kelompok Intervensi

Sebelum dan Sesudah diberikan Pembelajaran PUP

\begin{tabular}{cccc}
\hline Kelompok & $\mathrm{n}$ & Rata - rata & Nilai $p$ \\
Intervensi & 6 & 66,11 & 0,046 \\
\hline Pretest & 6 & 85 & \\
Postest & & & \\
\hline
\end{tabular}

Hasil analisis pada Tabel 2 menunjukkan bahwa ada perbedaan yang signifikan antara rata - rata nilai perilaku kelompok intervensi setelah diberikan pembelajaran PUP dengan nilai $p$ sebesar 0,046.

Tabel 3

Perbedaan Rata - rata Nilai Perilaku Kelompok Kontrol Sebelum dan Sesudah diberikan Pembelajaran PUP

\begin{tabular}{cccc}
\hline Kelompok Kontrol & $\mathrm{n}$ & Rata - rata & Nilai $p$ \\
\hline Pretest & 11 & 54,07 & 0,005 \\
Postest & 11 & 71,69 & \\
\hline
\end{tabular}

Hasil analisis pada Tabel 3 menunjukkan bahwa ada perbedaan yang signifikan antara rata - rata nilai perilaku kelompok kontrol setelah diberikan pembelajaran PUP dengan nilai $p$ sebesar 0,005 .

Tabel 4

Perbedaan Rata - rata Nilai Perilaku PUP antara Kelompok Intervensi dan Kelompok Kontrol Sesudah diberikan Pembelajaran PUP

\begin{tabular}{lccc}
\hline Kelompok Sampel & $\mathrm{n}$ & Rata - rata & Nilai $p$ \\
\hline Intervensi & 6 & 85 & 0,039 \\
Kontrol & 11 & 71,69 & \\
\hline
\end{tabular}

Hasil analisis pada Tabel 4 menunjukkan bahwa ada perbedaan yang signifikan antara rata - rata nilai perilaku PUP antara kelompok intervensi dan kelompok kontrol sesudah diberikan pembelajaran PUP dengan nilai $p$ sebesar 0,039 .

\section{Pembahasan}


Hasil analisis menunjukkan bahwa rata - rata nilai perilaku PUP remaja yang diberikan pembelajaran PUP semakin meningkat, baik pada kelompok intervensi (menggunakan tutor sebaya) maupun pada kelompok kontrol (tidak menggunakan tutor sebaya). Hasil belajar sesorang dipengaruhi oleh banyak faktor antara lain: cara belajar, disiplin, suasana lingkungan belajar, metode pembelajaran, motivasi dan karakteristik peserta pembelajaran ${ }^{10}$. Masa remaja memerlukan ekstra pengertian, bimbingan dan dukungan dari keluarga dan lingkungan sekitarnya $^{11}$.

Hasil penelitian ini juga menemukan bahwa metode pembelajaran menggunakan tutor sebaya secara signifikan dapat meningkatkan perilaku PUP. Beberapa penelitian serupa $^{6,7,8}$, juga mengungkapkan bahwa ada pengaruh metode tutor sebaya terhadap kedisiplinan, prestasi belajar dan meningkatkan ketuntasan belajar. Pembelajaran dengan tutor sebaya dapat memanfaatkan kemampuan tutor dalam memberikan pengajaran dan pengarahan untuk mencapai solusi dan pemahaman sesuai dengan tujuan pembelajaran. Selain itu, dalam proses pembelajaran dengan menggunakan tutor sebaya terjadi proses membangun pengetahuan sehingga seorang tutor akan mendapatkan manfaat ketika memberikan penjelasan kepada tutee, tutor mengintegrasikan konsep dan prinsip serta menghasilkan ide baru. Pertanyaan yang spesifik dan mendalam dari tutee dapat merefleksikan pengembangan pengetahuan dan tutor membantu proses penguatan pemahamannya $^{12,13}$. Selain faktor proses pembelajaran menggunakan tutor teman sebaya, peningkatan perilaku PUP tersebut juga dapat disebabkan karena faktor lainnya seperti kondisi lingkungan belajar yang kondusif di Aula Kantor Camat Abiansemal sangat luas, ventilasi dan sirkulasi udaranya sangat baik sehingga sangat mendukung proses pembelajaran dan interaksi diantara peserta. Selain itu, setiap peserta juga diberikan buku saku yang dapat dipelajari di rumah untuk memperkaya ilmu pengetahuan tentang PUP dan sebagian besar memiliki latar belakang pendidikan menengah. Di institusi pendidikan menengah, sudah ada kurikulum yang membahas tentang kesehatan reproduksi remaja sehingga sangat penting bagi pihak sekolah untuk memotivasi remaja untuk berperilaku seksual yang sehat ${ }^{14}$.

\section{Simpulan dan Saran}

Berdasarkan paparan hasil penelitian di atas dapat disimpulkan bahwa pembelajaran menggunakan tutor teman sebaya berperan dalam meningkatkan perilaku PUP pada remaja pengelola STT di Abiansemal, 
Badung tahun 2015. Pihak-pihak yang terkait dalam memberikan pembelajaran kepada remaja STT diharapkan untuk mempertimbangkan penggunaan metode pembelajaran menggunakan tutor teman sebaya. Selanjutnya bagi para peneliti yang tertarik melakukan penelitian yang terkait dengan remaja STT, untuk mengembangkan penelitian ini, dengan menambah besar sampel, sampai memenuhi syarat untuk analisis parametrik.

\section{Daftar Pustaka}

1. BKKBN. Keterampilan Hidup dalam Program Penyiapan Kehidupan Berkeluarga bagi Remaja. Jakarta: BKKBN. 2010.

2. RI, Presiden. Undang-undang Perkawinan. Jakarta: Pemerintah RI. 2010.

3. Muadz, M.M., Fathonah, S., Sapri, E.A. dan Moeliono, L. Pendewasaan Usia Perkawinan dan Hak - hak Reproduksi Bagi Remaja. Jakarta: BKKBN Direktorat Remaja dan Perlindungan. 2008.

4. Hakimi, M. Ilmu Kebidanan: Patologi dan Fisiologi Persalinan. Yogyakarta: Penerbit Andi \& Yayasan Essentia Medica (YEM). 2010.

5. Ekowati. Pembelajaran Inovatif sebagai Solusi Dominasi Pembelajaran Guru: Life Skill SMA Jawa Timur. Surabaya: 2009.

6. Maryuni, S., Narbuko, Susetya, E.B., Supriyono, Samiaji, A. \& Utami, S. Pendekatan Kooperatif Tutorial Teman Sebaya untuk Meningkatkan Kedisiplinan Siswa Kelas VII A SMP Negeri 3 Sidomoro. Pacitan. 2009. Tersedia di https://www.google.co.id/ files.wordpress.com $\% 2 \mathrm{~F} 2009 \% 2 \mathrm{~F} 09 \%$
2Fmetode-tutor-sebaya-proposal-jadi. doc. Diakses 30 April 2015.

7. Arjanggi, R. \& Suprihatin, T., Metode Pembelajaran Tutor Teman Sebaya Meningkatkan Hasil Belajar Berdasar Regulasi Diri. Makara, Sosial Humaniora. 2010; 14 (2) Desember: 91-97

8. Satriyanti, A.R. Penerapan Metode Pembelajaran Tutor Sebaya Terhadap Peningkatan Prestasi Belajar Ipa Pokok Bahasan Alat Indra Bagi Siswa Kelas IV MI Tarbiyatul Ulum Desa Jembrak Kecamatan Pabelan Kabupaten Semarang Tahun Ajaran 2013/2014. Skripsi. Salatiga: STAIN 2014.

9. Dantes, Metode Penelitian. Yogyakarta: Penerbit Andi. 2012.

10. Sugesti, R. Hubungan Faktor - faktor Ekstern terhadap Prestasi Belajar Mata Kuliah Kesehatan Reproduksi Mahasiswa DIV Kebidanan STIKIM. Jurnal Ilmu Kebidanan Indonesia. 2015; 5 (2) Juni: 149-162.

11. Pinem, S. Kesehatan Reproduksi dan Kontrasepsi. Jakarta: Trans Invo Media. 2009.

12. Roscoe, R.D., \& Chi, M.T.H. Understanding tutor learning: Knowledge building and knowledgetelling in peer tutors' explaination and questions. Review of Education Research. 2007. 77 (4): 534-574.

13. Depaz, I., \& Moni, R.W. Using peer teaching to support co-operative learning in undergraduate pharmacologi. Bioscience Education Journal, 2008. 11: 98-108.

14. Iryanti. Pengaruh Pendidikan Kesehatan Reproduksi melalui Metode Pendidikan Sebaya Terhadap Pengetahuan dan Sikap Remaja dalam Pencegahan Kehamilan Tak Diinginkan (KTD) di SMKN 15 Kotamadya Bandung. Jurnal Kesehatan Kartika Stikes A. Yani. 2009: 30-39 